\title{
Accumulation of Allelic Changes at Chromosomes 7p, 18q, and 2 in Parathyroid Lesions of Uremic Patients
}

\author{
Anetta Nagy, Jerzy Chudek, and Gyula Kovacs \\ Laboratory of Molecular Oncology (AN, GK), Department of Urology, Ruprecht-Karls University, Heidelberg, \\ Germany; and Department of Nephrology, Endocrinology and Metabolic Diseases (JC), Silesian Medical School, \\ Katowice, Poland
}

SUMMARY: We examined by microsatellite allelotyping 69 hyperplastic lesions of the parathyroid glands from 23 patients with refractory, uremic hyperparathyroidism. Allelic changes, at least at one chromosomal arm, were found in 31 of the 69 lesions (43\%). Alteration at a single chromosome was seen in 14 lesions and at two to four chromosomes in 11 lesions, and there were five to eight alterations in 5 nodules. Allelic imbalance occurred most frequently at chromosome $7 p$ between the EGFR gene and locus D7S817 (16\%), at 18q between loci D18S61 and D18S70 (14\%), and at chromosome 2 between D2S380 and D2S1391 (9\%). X-inactivation study showed a monoclonal growth in 18 of 29 nodules in females, and a loss of the $Y$ chromosome was seen in 8 of the 39 nodules obtained from males. Our results suggest that the uremic "hyperplastic" nodules have a molecular pathway distinct from those known for sporadic primary parathyroid adenomas. (Lab Invest 2001, 81:527-533).

\begin{abstract}
S econdary hyperparathyroidism (SHPT) is one of $\int$ the most serious complications of chronic renal insufficiency, characterized by the overgrowth of parathyroid cells and finally by an uncontrolled parathyroid hormone secretion. It is suggested that enlargement of the parathyroid glands starts with diffuse and polyclonal growth, and then some of the monoclonal foci progress to nodular hyperplasia and possibly to parathyroid adenoma (Fukagawa, 1999). The hyperplastic growth is induced by the low level of calcium and calcitriol and high concentrations of phosphate in serum. The proliferation of parathyroid cells is reversible in this stage. Larger monoclonal nodules, however, have a low density of calcitriol receptor and calcium-sensing receptor $(\mathrm{CaR})$, making them refractory to active vitamin D therapy (Fukuda et al, 1993). Long-term stimulation of parathyroid cells may result in tertiary hyperparathyroidism with autonomous hyperfunction and hypercalcemia, and uremic, "hyperplastic" nodules may behave clinically like primary parathyroid adenomas (PA) (Brandi, 1997; Fukagawa, 1999; Ritz et al, 1995).

Therefore, the question arises whether primary PAs and uremic hyperplastic nodules share a common molecular pathology. Most genetic studies have been carried out on primary PAs. Rearrangement and overexpression of the cyclin D1 oncogene (PRAD1), as well as loss of heterozygosity ( $\mathrm{LOH})$ at and distal to the
\end{abstract}

Received November 29, 2000.

This work was supported by a grant of the German Research Council (Ko 841/13-1).

Address reprint requests to: Dr. Gyula Kovacs, Laboratory of Molecular Oncology, Department of Urology, Ruprecht-Karls University, Im Neuenheimer Feld 365, Rm 002, D-69120 Heidelberg, Germany. E-mail: gyula.kovacs@urz.uni-heidelberg.de multiplex endocrine neoplasia type 1 (MEN1) gene locus at chromosome 11q13, was found in a subset of PAs (Chakrabarti et al, 1998; Heppner et al, 1997; Rosenberg et al, 1991). LOH at chromosome 1p, but no mutation of the RAD54, has been observed in sporadic tumors (Carling et al, 1999; Cryns et al, 1995; Tahara et al, 1997). Comparative genomic hybridization and allelotyping studies of sporadic PAs detected DNA loss at the highest frequency on chromosomes $1 p, 6 q, 11 p, 11 q, 15 q, 17 p$, and 22q, whereas chromosomal gains have been described on 19p, 16p, and 7 (Farnebo et al, 1999; Palanisamy et al, 1998; Tahara et al, 1996).

The genetic changes associated with the nodular/ clonal growth of uremic hyperplastic lesions are not yet known. A low rate of $\mathrm{LOH}$ distributed randomly throughout the genome has been described in hyperplastic nodules of SHPT (Chudek et al, 1998; Koshiishi et al, 1999). X-chromosome inactivation studies suggest that a substantial number of hyperplastic parathyroid nodules in uremic patients arise by monoclonal growth (Arnold et al, 1995; Chudek et al, 1998). Therefore, such lesions may represent a tumorous cell proliferation in which clonal genetic alterations are expected. To obtain an overview of genetic alterations in hyperplastic parathyroid lesions, we have extended our previous microsatellite studies (Chudek et al, 1998) to an analysis of an additional 28 loci at distinct chromosomal regions in 69 lesions of 23 uremic patients.

\section{Results}

\section{Microsatellite Allelotyping}

The present findings were evaluated, together with those obtained earlier, by analyzing 12 chromosomal 
arms (Chudek et al, 1998). Allelic changes occurred in 31 of the 69 lesions (45\%). Alteration at only one chromosomal arm was seen in 14 lesions, at two to four chromosomal regions in 11 nodules, and at five to eight chromosomal regions in 5 lesions (Tables 1 and 2).

Genetic alterations occurred at chromosome 7 in 11 of 69 (16\%) nodular hyperplasias. An allelic imbalance (Al) was seen at all informative loci along the short and long arms of chromosome 7 in six lesions. Two nodules showed $\mathrm{Al}$ exclusively at EGFR (CA repeat within intron 1 of the EGFR gene) by retention of heterozygosity at loci D7S817 and D7S1797. Two other lesions revealed allelic changes at locus D7S817 and retained heterozygosity without allelic changes at the EGFR locus. One of them also showed allelic change exclusively at locus D7S2847 (at the MET gene). One additional lesion had allelic changes at loci D7S817 and EGFR by retaining heterozygosity at the HGF. Thus, partial allelic changes determine the smallest overlapping $\mathrm{Al}$ between loci D7S817 and EGFRca1.

Alteration at chromosome $18 q$ occurred in 10 cases (14\%). One example is shown in Figure 1. Four lesions showed allelic changes at loci D18S1119, D18S61, and D18S58 and retention of heterozygosity without allelic changes at locus D18S70, whereas two lesions displayed allelic changes at locus D18S70 and retention of heterozygosity at loci D18S1119 and D18S61, respectively. In three lesions from the same patient, $\mathrm{AI}$ at locus D18S58 and retention of heterozygosity at flanking loci was seen. Thus, the smallest lesion was localized between loci D18S61 and D18S70. Al at chromosome 2 was seen in 6 cases (9\%). Selective allelic changes at locus D2S380 was detected in 3 cases, selective changes at locus D2S1391 in 2 lesions, and allelic changes at both loci in one case. Thus, the specific allelic change might be localized between the two markers and should be analyzed next. Al at either chromosome 16p13.13 (D16S407) or chromosome 16q24.2 (D16S520), or at both, occurred in 5 cases (7\%). Genetic changes were seen at chromosome 14 in only four lesions, but in three of them a $\mathrm{LOH}$ occurred. None of the lesions had allelic changes at the p53 gene locus at chromosome 17p13, and only two of them showed Al at locus D17S806 (17q21.31). Four lesions had an allelic change at chromosome $19 q$, one of them a LOH. Three lesions showed Al at chromosome 20p (D20S194), one at 20q (D20S120),

Table 1. Pathologic Features and Genetic Alterations of Female Patients

\begin{tabular}{|c|c|c|c|c|}
\hline Patients & $\begin{array}{l}\text { Volume of } \\
\text { gland }\left(\mathrm{cm}^{3}\right)\end{array}$ & Morphology & $\mathrm{X}$ inactivation & Allelic changes \\
\hline HD68 A & 0.9 & $\mathrm{~N}$ & $\mathrm{M}$ & $1 p, 12 q$ \\
\hline HD70 A & 0.6 & D & $\mathrm{NI}$ & $2 q, 7 p, 16 q, 17 q, 19 q$ \\
\hline \multirow{4}{*}{ HD76 } & 0.1 & $\mathrm{~N}$ & $P$ & \\
\hline & 1.3 & $\mathrm{~N}$ & M & \\
\hline & 1.5 & $\mathrm{~N}$ & $P$ & \\
\hline & 1.5 & $\mathrm{~N}$ & $P$ & \\
\hline \multirow{4}{*}{ HD77 } & 12.5 & $\mathrm{~N}$ & $M$ & $7 p q, 11 p q, 14 q, 19 q, 20 p$ \\
\hline & 0.1 & $\mathrm{~N}$ & $M$ & $20 q$ \\
\hline & 0.6 & $\mathrm{~N}$ & M & $7 p q, 16 p q, 20 p q$ \\
\hline & 0.25 & $\mathrm{~N}$ & $\mathrm{P}$ & \\
\hline HD79 A & 1.1 & $\mathrm{~N}$ & M & $7 p q, 14 q, 18 q, 19 q, 20 p$ \\
\hline \multirow{4}{*}{ HD90 } & 0.3 & $\mathrm{~N}$ & $\mathrm{M}$ & \\
\hline & 0.4 & D & $\mathrm{P}$ & \\
\hline & 0.1 & $\mathrm{~N}$ & M & \\
\hline & 0.1 & $\mathrm{~N}$ & M & \\
\hline HD178 A & 1.0 & $\mathrm{~N}$ & M & \\
\hline HD223 A & 0.3 & $\mathrm{~N}$ & $\mathrm{P}$ & $20 p$ \\
\hline B & 1.7 & $\mathrm{~N}$ & M & \\
\hline C & 0.4 & $\mathrm{~N}$ & M & \\
\hline $\mathrm{D}$ & 0.7 & $\mathrm{~N}$ & M & $7 \mathrm{pq}$ \\
\hline HD224 A & 1.8 & $\mathrm{~N}$ & $\mathrm{M}$ & $1 p, 6 q, 14 q, 16 p q, 18 q, 22 q$ \\
\hline HD227 A & 5.2 & N & $\mathrm{P}$ & $\mathrm{Xq}$ \\
\hline B & 0.8 & $\mathrm{~N}$ & $\mathrm{P}$ & \\
\hline C & 2.4 & $\mathrm{~N}$ & M & \\
\hline $\mathrm{D}$ & 1.5 & $\mathrm{~N}$ & M & $\mathrm{Xq}$ \\
\hline HD229 A & 0.6 & N & $\mathrm{P}$ & \\
\hline B & 0.2 & $\mathrm{~N}$ & $P$ & \\
\hline C & 0.5 & $\mathrm{~N}$ & $\mathrm{P}$ & \\
\hline HD236 A & 5.7 & $\mathrm{~N}$ & M & \\
\hline B & 11.2 & $\mathrm{~N}$ & M & \\
\hline
\end{tabular}

N, nodular; D, diffuse; M, monoclonal; P, polyclonal; NI, noninformative. 
Table 2. Pathologic Features and Genetic Alterations of Male Patients

\begin{tabular}{|c|c|c|c|c|}
\hline Patients & $\begin{array}{l}\text { Volume of } \\
\text { gland }\left(\mathrm{cm}^{3}\right)\end{array}$ & Morphology & $\begin{array}{c}\text { Loss of } Y \\
\text { chromosome }\end{array}$ & Allelic changes \\
\hline HD69 A & 0.1 & $\mathrm{~N}$ & No & \\
\hline B & 0.25 & $\mathrm{~N}$ & No & \\
\hline C & 0.1 & $\mathrm{~N}$ & No & \\
\hline D & 0.2 & $\mathrm{~N}$ & No & $7 p$ \\
\hline HD89 $A_{1}$ & & $\mathrm{~N}$ & No & \\
\hline $\mathrm{A}_{2}$ & $1.7(\mathrm{~A})$ & $\mathrm{N}$ & No & \\
\hline$A_{3}^{2}$ & & $\mathrm{~N}$ & Yes & $2 q, 7 p q, 16 p q, 18 q$ \\
\hline$B$ & 0.9 & $\mathrm{~N}$ & No & \\
\hline C & 1.2 & $\mathrm{~N}$ & No & \\
\hline HD177 A & 3.0 & $\mathrm{~N}$ & Yes & $14 q, 18 q, 19 q$ \\
\hline B & 0.4 & $\mathrm{~N}$ & No & $18 q$ \\
\hline C & 1.4 & $\mathrm{~N}$ & No & $18 q$ \\
\hline D & 0.6 & $\mathrm{~N}$ & No & $18 q$ \\
\hline HD218 A & 0.2 & $\mathrm{~N}$ & Yes & $7 p q, 21 q$ \\
\hline B & 0.1 & $\mathrm{~N}$ & No & $7 p$ \\
\hline C & 0.25 & $\mathrm{~N}$ & No & $2 p q, 3 q, 4 p, 10 q, 13 q, 14 q, 18 q, 21 q$ \\
\hline D & 1.7 & $\mathrm{~N}$ & No & $2 p, 4 p, 5 q$ \\
\hline HD219 A & 0.8 & $\mathrm{~N}$ & No & $5 p q, 7 p, 17 q$ \\
\hline B & 1.2 & $\mathrm{~N}$ & Yes & $20 q, 21 q$ \\
\hline C & 3.0 & $\mathrm{~N}$ & No & $20 p q$ \\
\hline D & 0.6 & $\mathrm{~N}$ & Yes & \\
\hline HD222 A & 2.5 & $\mathrm{~N}$ & No & $3 q, 5 p q, 22 q$ \\
\hline B & 0.7 & $\mathrm{~N}$ & No & \\
\hline HD228 A & 0.2 & $\mathrm{~N}$ & No & $16 p$ \\
\hline B & 0.7 & $\mathrm{~N}$ & No & $2 p$ \\
\hline C & 0.1 & $\mathrm{~N}$ & No & $2 p$ \\
\hline HD234 A & 0.4 & $\mathrm{~N}$ & Yes & \\
\hline B & 0.4 & $\mathrm{~N}$ & Yes & \\
\hline C & 0.8 & $\mathrm{~N}$ & Yes & $18 q, 22 q$ \\
\hline D & 1.0 & $\mathrm{~N}$ & No & $7 p q$ \\
\hline HD238 A & 1.5 & $\mathrm{~N}$ & No & \\
\hline B & 1.7 & $\mathrm{~N}$ & No & \\
\hline C & 0.6 & $\mathrm{~N}$ & No & \\
\hline D & 0.7 & $\mathrm{~N}$ & No & \\
\hline HD239 A & 0.4 & $\mathrm{~N}$ & No & \\
\hline B & 1.9 & $\mathrm{~N}$ & No & \\
\hline C & 1.6 & $\mathrm{~N}$ & No & $7 p q$ \\
\hline D & 1.8 & $\mathrm{~N}$ & No & \\
\hline $\mathrm{HD} 240 \mathrm{~A}$ & 4.2 & $\mathrm{~N}$ & No & $1 p, 8 p, 10 q, 12 q, 19 q$ \\
\hline
\end{tabular}

N, nodular; $D$, diffuse.

and one nodule at both loci. Of interest, chromosome 21 showed $\mathrm{LOH}$ in two nodules and $\mathrm{Al}$ in one another.

We did not find allelic changes at chromosomes $1 \mathrm{q}$ (D1S1656), 3p (D3S1766 and D3S1289), 9p (D9S171), or 15q (D15S97, D15S165, D15S100) or at the p53 locus on 17p13.1. We did not find microsatellite instability at any of the 48 loci analyzed in the series of 69 parathyroid lesions.

\section{Loss of the Y Chromosome}

Loss of the $Y$ chromosome occurred in 8 of the 39 nodules obtained from male patients. Six of these nodules displayed genetic changes at autosomal chromosomes as well.

\section{Discussion}

Most patients suffering chronic renal failure with refractory hyperparathyroidism develop at least one parathyroid nodule of monoclonal origin (Arnold et al, 1995; Chudek et al, 1998). The clonal growth of parathyroid cells leads in some cases to tertiary hyperparathyroidism with autonomous hyperfunction presenting clinical symptoms similar to those of primary PA. Several studies confirmed DNA loss at chromosomal regions 1p (40\%), 6q (30\%), 11p (26\%), $11 q(34 \%)$, and $15 q(35 \%)$ and gains at chromosomes $7(12 \%)$ and $16 \mathrm{p}(11 \%)$ in primary PA (Farnebo et al, 1999, Palanisamy et al, 1998; Tahara et al, 1996). However, the specific genetic changes responsible for 


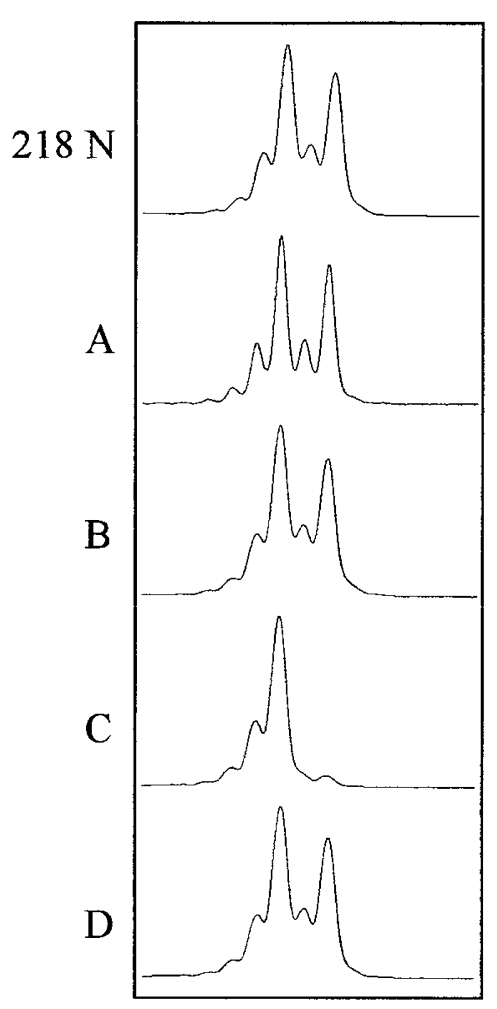

Figure 1.

Microsatellite analysis of multiple parathyroid nodules at locus D18S61 in Case HD218. The constitutional heterozygosity without allelic imbalance was retained in nodules $A, B$, and $D$, whereas nodule $C$ showed loss of heterozygosity (LOH) at this locus.

the tumorous growth of uremic hyperplastic nodules is poorly understood. Our present study detected recurrent allelic changes at chromosomes $2,7 p$, and $18 q$, which seem to be associated with clonal growth of parathyroid cells in SHPT. We detected allelic changes at chromosome $1 p$ in only 3 of 69 SHPT lesions and at chromosomes $6 \mathrm{q}, 11 \mathrm{p}$, and $11 \mathrm{q}$ in 1 of 69 nodules, and we did not find any change at chromosome $15 q$ in SHPT. These data suggest that clonal nodular lesions in uremic hyperparathyroidism carry genetic changes distinct from those occurring in primary PAs.

One genetic change seems to be common in both PA and SHPT. A comparative genomic hybridization $(\mathrm{CGH})$ study described a gain of chromosome 7 in $12 \%$ of PA (Farnebo et al, 1999). In our series, Al at chromosome 7p12-15 was the most common genetic change occurring in $16 \%$ of hyperplastic nodules obtained from SHPT. In two lesions, only the locus D7S817, but not the EGFRca1, was duplicated, suggesting that, not the EGFR, but another gene localized distally may be implicated in the development of nodular hyperplasia. The findings that EGFR and its ligand TGF- $\alpha$ are coexpressed in normal parathyroid glands as well as in PA also suggest that signaling through EGFR per se is not an explanation for cell proliferation in parathyroid lesions (Kvasnicka et al, 1997).

Two genetic changes occur preferentially in uremic parathyroid lesions. The allelic change at chromosome 2q between loci D2S380 and D2S1391 encompasses several genes including TGF- $\alpha$, EGR4, and the PTHR2 gene. The involvement of these genes by alteration of their expression or by mutation in the development of SHPT is not yet known. Contrary to our results, Farnebo et al (1999) did not find LOH at the PTHR2 region. We found allelic changes at chromosome $18 \mathrm{q}$ within a region of approximately $20 \mathrm{cM}$ excluding the $B C L-2$ locus in $14 \%$ of the uremic parathyroid nodules. Narrowing both chromosome 2 and $18 q$ regions to an appropriate size and cloning the genes will be necessary to specify the role of these genetic changes in the transition of clonal growth of parathyroid cells into autonomously growing nodules.

Alteration of genes involved in the normal function of the parathyroid glands has been discussed in relation to the pathological processes that occur during development of parathyroid lesions (Brandi, 1997; Fukagawa, 1999; Ritz et al, 1995). Activation of the $\mathrm{CaR}$ gene in parathyroid cells inhibits parathyroid hormone secretion. However, allelic changes at chromosome 3q21 do not include the CaR gene locus, and mutation analysis excluded the role of this gene in the development of nodular lesions in SHPT with resistance to calcitriol therapy (Cetani et al, 1999; Chudek et al, 1998; Degenhardt et al, 1998; Hosokawa et al, 1995). Inactivation of the vitamin D receptor (VDR at chromosome 12q) in parathyroid cells is suggested to be instrumental in clonal proliferation of parathyroid cells because cells carrying such lesions have an impaired response to the antiproliferative effect of 1,25-dihydroxyvitamin $D_{3}$ treatment (Fukuda et al, 1993). Also, no LOH or mutation of the VDR gene has been detected in parathyroid lesions in SHPT (Chudek et al, 1998).

In summary, we showed that genetic changes at chromosome 2 and $18 \mathrm{q}$ occur preferentially in hyperplastic parathyroid nodules in SHPT and excluded allelic changes at chromosomes 1p, 6q, 11p, 11q, $13 q, 15 q, 16 p$, and 19p, which are specific for primary PA. Our data suggest two alternative genetic pathways for the autonomous growth of parathyroid cells. The first pathway is a monoclonal growth of genetically altered cells leading to the development of primary PA. The second pathway involves a polyclonal proliferation of parathyroid cells followed by clonal nodular hyperplasia, which finally results in refractory hyperthyroidism, eg, in "secondary" PA. Although secondary PAs show genetic changes different from those seen in primary adenomas, both pathways lead clinically to the same monoclonal lesion refractory to therapy, and both types of lesions indicate surgical treatment.

\section{Materials and Methods}

\section{Patients and Tissue Specimens}

Parathyroid tissues and peripheral blood were obtained at surgery from 23 unselected patients (12 women and 11 men) with advanced hyperparathyroidism. All patients were refractory to medical treatment. 
One part of each specimen was fixed and embedded for histologic examination, and the remaining tissue was frozen in liquid nitrogen and stored at $-80^{\circ} \mathrm{C}$. Histologic diagnosis was established according to Harach and Jasani (1992). Nodular hyperplasia was diagnosed in 67 specimens, and diffuse hyperplasia was found in 2 specimens. Estimated gland volumes $\left(V=4 / 3 \pi r_{1} r_{2} r_{3}\right)$ and the most important clinical and histologic data are summarized in Table 2.

\section{DNA Extraction and Microsatellite Analysis}

DNA was isolated from peripheral blood and hyperplastic nodules. A single nodule from each nodular hyperplastic gland was used for DNA extraction. To avoid contamination with normal stromal cells, nodules were at first dissected from the rest of the parathyroid tissue, placed on a Petri dish, and covered with TRIS hydrochloride/EDTA (TE, pH 9). The cells then were pushed and scraped out from the nodules and the remaining stromal tissue was discarded. This procedure was controlled under an inverted microscope. DNA was then extracted after proteinase $\mathrm{K}$ digestion by phenol/chloroform from both leukocytes and parathyroid cells. We used 28 microsatellite markers for analyzing chromosomes: 2p (D2S380), 2q (D2S1391), 4p (D4S2366), 5p
(D5S819), 5q (D5S1720, D5S818, D5S816, D5S476), 7p (D7S817, EGFRca1), 7q (D7S1797, D7S2847, D7S1801), 8p (D8S264), 10q (D10S1744), 14q (D14S267), 16p (D16S407), 16q (D16S520), 17q (D17S806), 18q (D18S70, D18S1119, D18S61, D18S558), 19q (D19S246) 20p (D20S194), 20q (D20S120), 21q (D21S1436), and 22q (D22S1266). The primer sequences and location of the markers was obtained from the Human Physical Mapping Project at the Whitehead Institute for Biomedical Research (http://www.genome.wi.mit.edu) and from the Genome Database (http://gdbwww.gdb.org/gdb/gdbtop.html).

Polymerase chain reaction (PCR) was carried out in 96-well polycarbonate plates using a PTC 200 thermocycler (MJ Research Inc., Watertown, Massachusetts). DNA amplification was performed in a total volume of $10 \mu \mathrm{l}$ with $50 \mathrm{ng}$ genomic DNA, $200 \mu \mathrm{m}$ each dNTP, 2 pmol of Cy5-labeled forward primer, 2 pmol of reverse primer, $10 \mathrm{~mm}$ Tris- $\mathrm{HCl}(\mathrm{pH} 8.3), 50 \mathrm{~mm} \mathrm{KCl}$, $1.5 \mathrm{mM} \mathrm{MgCl}_{2}, 0.01 \%$ bovine serum albumin, and 0.5 U Taq DNA polymerase (Gibco BRL, Eggenstein, Germany). After 2 minutes of denaturation at $94^{\circ} \mathrm{C}$ the loci were amplified by 28 PCR cycles according to the following conditions: $94^{\circ} \mathrm{C}$ for 30 seconds, $55^{\circ} \mathrm{C}$ for 30 seconds, and $72^{\circ} \mathrm{C}$ for 40 seconds. After a final extension at $72^{\circ} \mathrm{C}$ for 5 minutes, the reaction was

Table 3. Clinical Data of Patients with Refractory Renal Hyperparathyroidism

\begin{tabular}{|c|c|c|c|c|c|c|c|c|}
\hline \multirow[b]{2}{*}{ Patient } & \multirow[b]{2}{*}{ Age/Sex } & \multirow[b]{2}{*}{$\begin{array}{c}\text { Clinical } \\
\text { diagnosis }\end{array}$} & \multirow[b]{2}{*}{$\begin{array}{l}\text { Time of } \\
\text { HD (yr) }\end{array}$} & \multicolumn{2}{|c|}{ Treatment $^{\mathrm{a}}$ (oral) } & \multicolumn{3}{|c|}{ Concentrations in serum } \\
\hline & & & & $\begin{array}{c}1,25(\mathrm{OH})_{2} \mathrm{D}_{3} \\
(\mu \mathrm{g} / \text { week })\end{array}$ & $\begin{array}{c}\mathrm{P} \\
\text { binder }\end{array}$ & $\begin{array}{c}\mathrm{Ca} \\
(\mathrm{mg} / \mathrm{dl})\end{array}$ & $\begin{array}{c}P \\
(m g / d l)\end{array}$ & $\begin{array}{c}\text { iPTH } \\
(\mathrm{pg} / \mathrm{ml})\end{array}$ \\
\hline HD68 & $66 / F$ & PN & 10 & - & + & 11.3 & 5.1 & 194 \\
\hline HD69 & $33 / \mathrm{M}$ & Unknown & 7 & 1.75 & - & 9.2 & 5.0 & 828 \\
\hline HD70 & $48 / F$ & GN & 5 & 1.75 & - & 10.5 & 5.2 & 1261 \\
\hline HD76 & $23 / F$ & GN & 4 & - & + & 10.2 & 6.4 & 1341 \\
\hline HD77 & $56 / F$ & PN & 14 & - & + & 10.8 & 6.5 & 520 \\
\hline HD79 & $56 / F$ & ADPKD & 7 & 1.75 & + & 11.2 & 8.1 & 1563 \\
\hline HD89 & $63 / \mathrm{M}$ & HT & 1 & - & - & 10.4 & 6.6 & 1051 \\
\hline HD90 & $36 / F$ & GN & 4 & - & + & 11.5 & 5.9 & 1673 \\
\hline HD177 & $44 / M$ & GN & 4 & - & + & 10.3 & 5.7 & 393 \\
\hline HD178 & $74 / F$ & Unknown & 8 & - & + & 10.8 & 5.3 & 241 \\
\hline HD218 & $69 / \mathrm{M}$ & GN & 4 & - & + & 11.4 & 6.8 & 875 \\
\hline HD219 & $67 / \mathrm{M}$ & Unknown & 6 & - & + & 10.2 & 5.8 & 1800 \\
\hline HD222 & $41 / \mathrm{M}$ & DN & 4 & - & - & 13.6 & 1.5 & 310 \\
\hline HD223 & $39 / F$ & PN & 11 & 10.5 & - & 10.2 & 6.4 & 2660 \\
\hline HD224 & $53 / F$ & HT & 1 & - & + & 10.9 & 6.4 & 2000 \\
\hline HD227 & $17 / F$ & PN & 3 & 9 & + & 11.5 & 5.8 & 1630 \\
\hline HD228 & 40/M & Unknown & 4 & 6 & + & 11.3 & 3.3 & 1630 \\
\hline HD229 & $59 / F$ & Unknown & 8 & - & - & 13.6 & 1.7 & 280 \\
\hline HD234 & 71/M & PN & 18 & 1.75 & + & 11.1 & 6.0 & 1250 \\
\hline HD236 & $62 / F$ & Unknown & 14 & - & - & 13.9 & 1.8 & 130 \\
\hline HB238 & $31 / \mathrm{M}$ & DN & 1 & - & + & 9.3 & 5.3 & 2354 \\
\hline HD239 & $58 / \mathrm{M}$ & Unknown & 4 & 1.75 & + & 10.4 & 5.2 & 1700 \\
\hline HD240 & $61 / \mathrm{M}$ & HT & 19 & 1.75 & + & 9.7 & 5.8 & 640 \\
\hline $\begin{array}{l}\text { Mean } \\
\pm S D\end{array}$ & $\begin{array}{c}50 \\
\pm 16\end{array}$ & & $\begin{array}{r}7 \\
\pm 5\end{array}$ & & & $\begin{array}{r}11.0 \\
\pm 1.2\end{array}$ & $\begin{array}{r}5.3 \\
\pm 1.6\end{array}$ & $\begin{array}{r}1103 \\
\pm 743\end{array}$ \\
\hline
\end{tabular}

HD, hemodialysis; GN, glomerulonephritis; PN, "pyelonephritis"/malformation; DN, diabetic nephropathy; HT, hypertensive nephropathy; ADPKD, polycystic kidney disease.

${ }^{a}$ At the time of surgery. 
stopped by adding $20 \mu \mathrm{l}$ of ALFexpress (Mallinckrodt Baker, Deventer, Holland) loading buffer (50 mм EDTA and $5 \mathrm{mg} / \mathrm{ml}$ Dextran Blue 2000 in 100\% deionized formamide).

Before loading, the PCR products from normal and tumor DNA were heat-denatured at $94^{\circ} \mathrm{C}$ for 2 minutes, then 3 to $5 \mu$ l were separated on $5 \%$ denaturing polyacrylamide gels (made of acrylamide:bisacrylamide $=19: 1$ ), on an automated DNA sequencer (ALFexpressll, Amersham/Pharmacia Biotech, Freiburg, Germany). The conditions of electrophoretic separation were $1500 \mathrm{~V}, 38 \mathrm{~mA}, 25 \mathrm{~W}$, and a constant gel temperature of $55^{\circ} \mathrm{C}$ in $1 \times$ Tris-borate-EDTA (TBE) buffer. The collected data were evaluated using the Fragment Manager (FM 1.2) (Amersham/Pharmacia, Biotech). We determined a decrease or increase of signal intensity at one allele to around $50 \%$ of the signal of the corresponding normal allele as an $\mathrm{Al}$, whereas the complete or nearly complete loss of signal is designated a LOH (see Figure 1). The term microsatellite instability is used only for cases where the allelic size in tumor tissues differs from that observed in the corresponding normal cells or when an additional new signal of different allelic size appears in the tumor.

\section{Analysis of the $X$ and $Y$ chromosomes}

PCR was performed as described above with the primers $A M X Y-1 F$ and $A M X Y-2 R$ (MWG Biotech, Ebersbach, Germany) to amplify a part of the $X-Y$ homologous region (Nakahori et al, 1991). After 2 minutes of denaturation at $94^{\circ} \mathrm{C}$, the samples were subjected to the following amplification program: 1 minute at $94^{\circ} \mathrm{C}, 1$ minute at $61^{\circ} \mathrm{C}$, and 2 minutes at $72^{\circ} \mathrm{C}$ for 30 cycles. The final extension time was increased to 10 minutes at $72^{\circ} \mathrm{C}$. DNA fragments were separated on a $1 \%$ agarose gel at $60 \mathrm{~V}$ for 90 minutes and visualized by staining with ethidium bromide.

\section{Acknowledgements}

We are indebted to Dr. F. Spielsberg and Dr. H. P. Mühlig, Department of Surgery, Martha Maria Hospital in Munich, Germany, for assistance in obtaining parathyroid specimens and clinical data.

\section{References}

Arnold A, Brown MF, Urena P, Gaz RD, Sarfati E, and Drüeke TB (1995). Monoclonality of parathyroid tumors in chronic renal failure and in primary parathyroid hyperplasia. $\mathrm{J}$ Clin Invest 95:2047-2053.

Brandi ML (1997). Molecular mechanisms of parathyroid hyperplasia and neoplasia. Horm Res 47:194-198.

Carling T, Imanishi Y, Gaz RD, and Arnold A (1999). Analysis of the RAD54 gene on chromosome $1 p$ as a potential tumor-suppressor gene in parathyroid adenomas. Int $\mathrm{J}$ Cancer 83:80-82.
Cetani F, Pinchera A, Pardi E, Cianferotti L, Vidgani E, Picone A, Miccoli P, Viacava P, and Marcocci C (1999). No evidence for mutations in the calcium-sensing receptor gene in sporadic parathyroid adenomas. J Bone Miner Res 14:878-882.

Chakrabarti R, Srivatsan ES, Wood TF, Eubanks PJ, Ebrahimi SA, Gatti RA, Passaro E, and Sawicki MP (1998). Deletion mapping of endocrine tumors localizes a second tumor suppressor gene on chromosome band 11q13. Genes Chromosomes Cancer 22:130-137.

Chudek J, Ritz E, and Kovacs G (1998). Genetic abnormalities in parathyroid nodules of uremic patients. Clin Cancer Res 4:211-214.

Cryns VL, Yi SM, Tahara H, Gaz RD, and Arnold A (1995). Frequent loss of chromosome arm 1p DNA in parathyroid adenomas. Genes Chromosomes Cancer 13:9-17.

Degenhardt S, Toell A, Weidemann W, Dotzenrath C, Spindler KD, and Grabensee B (1998). Point mutations of the human parathyroid calcium receptor gene are not responsible for non-suppressible renal hyperparathyroidism (Abstract). Kidney Int 53:556-561.

Farnebo F, Kytölä S, Teh BT, Dwight T, Wong FK, Höög A, Elvius M, Wassif WS, Thompson NW, Farnebo LO, Sandelin K, and Larsson C (1999). Alternative genetic pathways in parathyroid tumorigenesis. J Clin Endocrinol Metab 84:37753780 .

Fukagawa M (1999). Cell biology of parathyroid hyperplasia in uraemia. Am J Med Sci 317:377-382.

Fukuda N, Tanaka H, Tominaga $\mathrm{Y}$, Fukagawa M, Kurokawa $K$, and Seino $Y$ (1993). Decreased 1,25-dihydroxyvitamin $D_{3}$ receptor density is associated with a more severe form of parathyroid hyperplasia in chronic uremic patients. J Clin Invest 92:1436-1443.

Harach HR and Jasani B (1992). Parathyroid hyperplasia in tertiary hyperparathyroidism: A pathological and immunohistochemical reappraisal. Histopathology 21:513-519.

Heppner C, Kester MB, Agarwal SK, Debelenko LV, EmmertBuck MR, Guru SC, Manickam P, Olufemi SE, Skarulis MC, Doppman JL, Alexander RH, Kim YS, Saggar SK, Lubensky IA, Zhuang Z, Liotta LA, Chandrasekharappa SC, Collins FS, Spiegel AM, Burns AL, and Marx SJ (1997). Somatic mutation of the MEN1 gene in parathyroid tumours. Nat Genet 16:375378.

Hosokawa Y, Pollak MR, Brown EM, and Arnold A (1995). Mutational analysis of the extracellular $\mathrm{Ca}^{2+}$-sensing receptor gene in human parathyroid tumors. J Clin Endocrinol Metab 80:3107-3110.

Koshiishi N, Chong JM, Fukasawa T, Ikeno R, Tanaka A, Kanazawa K, Ogura M, Ebuchi M, Takizawa T, Funata N, and Fukayama M (1999). Microsatellite instability and loss of heterozygosity in primary and secondary proliferative lesions of the parathyroid gland Lab Invest 79:10511058.

Kvasnicka T, Wang W, Johansson H, Sandelin K, and Grimelius $L$ (1997). Apoptosis and growth factors in parathyroid adenomas. Horm Metab Res 29:544-548.

Nakahori Y, Hamano K, Iwaya M, and Nakagome $Y$ (1991). Sex identification by polymerase chain reaction by using $X-Y$ homologous primer. Am J Med Genet 39:472-473. 
Palanisamy N, Imanishi Y, Rao PH, Tahara H, Chaganti RSK, and Arnold A (1998). Novel chromosomal abnormalities identified by comparative genomic hybridization in parathyroid adenomas. J Clin Endocrinol Metab 83:1766-1770.

Ritz E, Stefanski A, and Rambausek M (1995). The role of the parathyroid glands in the uremic syndrome. Am J Kidney Dis 26:808-813.

Rosenberg CL, Kim HG, Shows TB, Kronenberg HM, and Arnold A (1991). Rearrangement and overexpression of D11S287E, a candidate oncogene on chromosome 11q13 in benign parathyroid tumors. Oncogene 6:449-453.
Tahara H, Smith AP, Gaz RD, Cryns VL, and Arnold A (1996). Genomic localization of novel candidate tumor suppressor gene loci in human parathyroid adenomas. Cancer Res 56:599-605.

Tahara H, Smith AP, Gaz RD, Zariwala M, Xiong Y, and Arnold A (1997). Parathyroid tumor suppressor on 1p: Analysis of the p18 cyclin-dependent kinase inhibitor gene as a candidate. J Bone Miner Res 12:1330-1334. 